\title{
Getting Smarter About Household Energy: The Who and What of Demand for Smart Meters
}

Citation: Fettermann, Diego Castro, Antonio Borriello, Andrea Pellegrini, Caroline G. Cavalcante, John M. Rose, and Paul F. Burke (2020). "Getting smarter about household energy: the who and what of demand for smart meters." Building Research \& Information (2020), 1-13. DOI: https://doi.org/10.1080/09613218.2020.1807896

ABSTRACT: The development of policies promoting smart meter adoption is essential to guide the transition towards sustainable use of resources such as water, electricity and gas, as well as inform smart-city initiatives. This article explores household preferences in terms of different smart meters and identifies the amounts that households are willing to pay for different smart meter configurations to monitor electricity, water and gas based on the features of their home including dwelling type, size and property value. To this aim, we employ a mixed multinomial logit model that accounts for the heterogeneity in customers' preferences for different smart meters. As a proof of concept, the proposed model is applied to a survey incorporating a discrete choice experiment carried out with 232 respondents in the Florianopolis metropolitan region, located in the south of Brazil. Our approach offers a number of advantages to facilitate the broader implementation of smart grid systems that would otherwise be overlooked using traditional approaches that rely on aggregated estimates for demand and willingness to pay for proposed schemes.

KEYWORDS: household consumption, water consumption, energy consumption, intelligent buildings, stated preference, discrete choice modelling, Mixed Multinomial Logit Model 


\section{THE WHO AND WHAT OF DEMAND FOR SMART METERS}

\section{Authors:}

Diego Castro Fettermann ${ }^{\mathrm{a}^{*}}$, Antonio Borriello ${ }^{\mathrm{b}}$, Andrea Pellegrinic ${ }^{\mathrm{c}}$, Caroline G. Cavalcante ${ }^{\mathrm{d}}$,

John M. Rose ${ }^{e}$ and Paul Burke ${ }^{f}$

${ }^{a}$ Federal University of Santa Catarina, Entrepreneurship and Innovation Laboratory, Campus Universitário Reitor João David Ferreira Lima, Trindade, Florianopolis, Santa Catarina, Brazil. d.fettermann@ufsc.br * Corresponding Author

${ }^{\mathrm{b}}$ University of Technology Sydney, Centre for Business, Intelligence \& Data Analytics (BIDA), Building 8, 14-28 Ultimo Road, Ultimo NSW 2007, Sydney, Australia. Antonio.Borriello@uts.edu.au

${ }^{\mathrm{c}}$ University of Technology Sydney, Centre for Business, Intelligence \& Data Analytics (BIDA), Building 8, 14-28 Ultimo Road, Ultimo NSW 2007, Sydney, Australia. Andrea.Pellegrini@uts.edu.au

${ }^{\mathrm{d}}$ Federal University of Santa Catarina, Entrepreneurship and Innovation Laboratory, Campus Universitário Reitor João David Ferreira Lima, Trindade, Florianopolis, Santa Catarina, Brazil. carolinegobbosa@gmail.com

${ }^{\mathrm{e}}$ University of Technology Sydney, Centre for Business, Intelligence \& Data Analytics (BIDA), Building 8, 14-28 Ultimo Road, Ultimo NSW 2007, Sydney, Australia. John.Rose-1@uts.edu.au

${ }^{\mathrm{f}}$ University of Technology Sydney, Centre for Business, Intelligence \& Data Analytics (BIDA), Building 8, 14-28 Ultimo Road, Ultimo NSW 2007, Sydney, Australia. Paul.Burke@uts.edu.au

\section{To read more from these authors:}

Diego Fettermann

https://scholar.google.com/citations?user=YAfOPMQAAAAJ\&hl=en\&oi=sra

Antonio Borriello

https://scholar.google.com/citations?user=YDyub9gAAAAJ\&hl=en\&oi=sra

Andrea Pellegrini

https://scholar.google.com/citations?user=hjFO8s4AAAAJ\&hl=en\&oi=sra

John M. Rose:

https://scholar.google.com/citations?user=_RgQyIAAAAAJ\&hl=en\&oi=sra

Paul F. Burke

https://scholar.google.com/citations?user=0nbaZEwAAAAJ\&hl=en\&oi=ao 


\section{THE WHO AND WHAT OF DEMAND FOR SMART METERS}

\section{INTRODUCTION}

In a smart city environment, smart meters represent the primary interface between smart grid technologies and dwellings (Ellaban and Abu-Rub, 2016; Bugden and Stedman, 2019; Avancini et al., 2019). Whilst there is no universally accepted definition of what constitutes a smart meter (Darby, 2008; Schwartz et al., 2015; Sovacool et al., 2017), the terms "advanced meter" or "smart meter" are frequently used to cover a wide range of systems. These terms also incorporate digital meters, automated meters, retrofitted meters, two-way communication devices, monitors and displays (Darby, 2008; Darby 2010). The general agreement on the broad definition of smart meters is that it refers to devices that can measure resource consumption over time, store usage data for multiple periods, and allows for individual households, as well as suppliers, to readily access this data (Darby, 2008; Yang et al., 2019). This allows households to reduce their expenditure by altering usage activities in response to this customized information (Lienert and Carson, 2011; Gerpott and Paukert, 2013; Davies et al., 2014). Relying on a two-way communication system between customer and suppliers or grid operators, associated smart meter devices also provide automated reading of resource consumption (Darby, 2010, Sovacool et al., 2017) and assists in identifying occurrences of theft and fraud (Yip et al., 2017).

With access to the internet, smart meters offer the ability to communicate with other equipment, enabling real-time monitoring of resource consumption via connected devices, such as mobile phones (Alahmad et al., 2012). The information reported on mobile apps facilitates the management of resource generation and distribution (Marvin et al., 1999; Cherukutota and Jadhav, 2016). In turn, a notable advantage of smart meters is that this real-time information about their consumption embodies a valuable stimulus for households to alter behaviors and to realize significant savings on their utility expenditures (Marvin et al., 1999; Darby, 2006; Gerpott and Paukert, 2013; Davies et al., 2014; Albani et al., 2017). To date, standard utility bills have been the more common form of consumption feedback provided every month, or even only every three months, as in Australia. This represents a relatively long delay for the consumer to obtain useful information about their usage and makes it difficult for them to tie this back to specific details of 


\section{THE WHO AND WHAT OF DEMAND FOR SMART METERS}

excess consumption practices (e.g., tied to time of use or to particular appliances). Smart meter implementation represents, therefore, an important mechanism to increase environmental awareness (Marvin et al., 1999; Alahmad et al., 2012; Mogles et al., 2017; Avancini et al., 2019; Yang et al., 2019; Peltomaa et al., 2020) and presents a trigger to immediate forms of behavioral change.

Nowadays, many countries are implementing policies to incentivize smart meter adoption (Yang et al., 2019). For example, the European Union (EU) Electricity Directive instructed EU member states to achieve $80 \%$ of smart meter implementation among domestic consumers by 2020 (EU, 2009). In many countries, the installation of smart meters is part of an extensive smart grid project and is carried out by suppliers (Giordano and Fulli, 2012; Siano, 2014), such as is the case in Australia (AER, 2018), United Kingdom (Anderson and White, 2009; Lienert and Carson, 2011), France (Montginoul and Vestier, 2018) and Sweden (Vassileva et al., 2012). According to the National Agency of Energy (ANEEL), the initiatives undertaken to install a greater number of smart household meters in Brazil are yet to be embraced by consumers (ANEEL, 2012, Carvalho, 2015). One exception has been in the success of initiatives where smart meters have been provided by the suppliers (Di Santo et al., 2015).

Whilst the literature is rich of studies focusing on smart meters for electricity (Schwartz et al., 2015; Albani et al., 2017), less research has been offered in the context of water control (e.g., Stewart et al., 2013; Sønderlund et al., 2016; Liu et al., 2017). One difficulty in generalizing findings from other utility contexts is that central water control units are often installed outside of household dwellings, which is a less common practice seen in the context of electricity metering (Peltomaa et al., 2020). Research into the demand for smart readers of gas consumption is even less frequent and is commonly conducted together with electricity control (e.g., Van Houwelingen and Van Raaij, 1989; Bonino et al., 2012; Buchanan et al., 2015). More recent literature has begun to investigate the potential benefits that customers can realize when provided with smart meters that integrate multiple utilities (Rhodes et al., 2014; Lloret et al., 2016; Liu et al., 2017; Stewart 


\section{THE WHO AND WHAT OF DEMAND FOR SMART METERS}

et al., 2018; Fettermann et al., 2020). Much of this work considers the potential profitable market opportunity such integration presents (Yang et al., 2019; Fettermann et al., 2020).

In order to assess customers' expectations and preferences regarding smart meter configurations, recent studies have taken into account many factors, such as trust, privacy, security, reliability, and usefulness (e.g., Chou and Yutami, 2014; Chen et al., 2017; Peters et al., 2018; Düştegör et al., 2018; Alkawsi et al., 2018; Bugden and Stedman, 2019; van de Kaa et al., 2020). However, fewer studies have explored the importance of existing home features on customers' decisions to adopt smart meters, such as household resources expenditure (e.g., Chen et al., 2017; Düstegör et al., 2018, Henn et al., 2019) or dwelling size (e.g., Düstegör et al., 2018; Henn et al., 2019). Other important home features, such as the current type of water, electricity or gas supply, as well as dwelling type and property value, could also affect customers' decision to adopt smart meters, but have not been explored in the literature to date to the best of the authors' knowledge. In face of previous literature, the research problem addressed in this paper is: What is the preference among various smart meter configurations that integrate the monitoring of electricity, water and gas? Our research approach further considers how such preferences - and related measures of willingness to pay (WTP) for these configurations - may be heterogeneous across dwellings with different household characteristics.

We attempt to fill the gap in the literature outlined above in several ways. First, we investigate which home features affect the adoption of smart meters for three utilities, namely water, electricity and gas. Second, we present a smart modular architecture that integrates the real-time monitoring of these different utilities (i.e. metering for combinations of water, electricity, and/or gas) that can be managed through an app via a mobile phone. Finally, we present a random utility model to identify household preferences for different smart meters. This model forecasts the amounts that individual households - based on their characteristics - are willing to pay for different smart meter configurations with or without the mobile app. We do so via the use of a mixed multinomial logit model (MMLM), which avoids the assumption that individual households are homogenous with respect to each other in their valuation of smart meter attributes 


\section{THE WHO AND WHAT OF DEMAND FOR SMART METERS}

or the app (Train, 2003). By doing so, our findings avoid any erroneous conclusions about WTP that arise from aggregating over households with heterogeneous preferences (Hutchinson et al., 2000). The research approach and model is applied to data gathered from a survey of 232 respondents from the metropolitan region of Florianopolis, which is located in the south of Brazil.

\section{POTENTIAL SAVINGS}

Smart meters provide customers with a large amount of data in the form of personalized feedback (Kaufmann et al., 2013). This information is usually provided via in-home displays (e.g., Vassileva et al., 2012; Stewart et al., 2013; Schultz et al., 2015; Albani et al., 2017) or mobile apps available on a smartphone or tablet (Avancini et al., 2019; Wemyss et al., 2019). With this real-time information, consumers are able to respond by understanding how changes in behaviors influence resource usage and ultimately economic outcomes, thereby altering resource consumption. In turn, empirical evidence from the existing literature shows that it is possible for consumers to save resources and money by adopting smart meters (e.g., Darby, 2006; Alahmad et al., 2012; Vassileva et al., 2012; Gans et al., 2013; Davies et al., 2014; Liu et al., 2017; Mogles et al., 2017; Liu, Mukheibir, 2018; Montginoul and Vestier, 2018; Wemyss et al., 2019). The savings realized depend on several factors including the utility monitored (Sønderlund et al., 2016), the duration of monitoring (e.g., Köhler, 2017), as well as sociodemographic and cultural characteristics of the household's members (e.g., Ehrhardt-Martinez et al., 2010; Martinsson et al., 2011). However, several studies have questioned whether consumers experience difficulty in maintaining resource reduction in the long run (Ehrhardt-Martinez et al., 2010; Alahmad et al. 2012; Schultz et al., 2015; Liu et al., 2017; Wemyss et al., 2019).

The literature also suggests that changes in behavior induced by feedback via smart meters can be supported with a range of other instruments (e.g., Owen and Ward, 2006; Fischer, 2008; Darby, 2010; Vassileva et al., 2013; Buchanan et al., 2014; Liu et al., 2017; Albani et al., 2017). Of particular note is the complimentary value offered with various economic incentives (Gans et al., 2013; Vassileva et al., 2013), mechanisms to stimulate salience regarding the care for the environment (Mogles et al., 2017; Rausser et al., 2018), providing tips to reduce consumption 


\section{THE WHO AND WHAT OF DEMAND FOR SMART METERS}

according to weather forecasts (Gans et al., 2013, Liu et al., 2017), or offering games and challenges to induce behavioral changes (Vassileva et al., 2012; Zehir et al., 2019; Wemyss et al., 2019).

Despite the evidence of success for smart meter introduction and role of supporting initiatives have had in many settings, there have also occurred several unsuccessful cases to introduce smart meters around the world (e.g., Bertoldo et al., 2015; Montginoul and Vestier, 2018; Jegen and Philion, 2018; Bugden and Stedman, 2019; Kumar, 2019). For example, several initiatives have reported an increase in the number of customer complaints regarding smart meter installation, which stems from increases in bill amounts due to the improved accuracy in consumption measurement (Krishnamurti et al., 2012; Bugden and Stedman, 2019). In other cases, poor communication to customers about smart meter features (Bertoldo et al., 2015), the achievement of moderate savings relative to expectations (Balta-Ozkzan et a., 2014), loss of privacy (Bugden and Stedman, 2019), and potential health risks associated with radiofrequency (Jegen and Philion, 2018) have also been highlighted as problematic. These issues arising reduce customers' engagement towards smart meters and their effective use to improve awareness about finite natural resources utilization. The common conclusion drawn from each of these cases is that a better understanding of customer needs is critical for an efficacious implementation. These results emphasize the importance of forecasting methods that better comprehend customers' expectations and preferences for smart meter devices, as well as the affordability of these smart devices at the individual household level.

\section{METHOD}

A widely used approach to explore consumer preferences has been the use of discrete choice experiments (DCEs) and associated discrete choice modelling (DCMs). For example, DCEs and DCMs have been applied to understand consumer demand in the context of transport (e.g., Greene and Hensher, 2003), energy (e.g., McNair et al., 2011), environmental economics (e.g., Willis et al., 2005), marketing (e.g., Burke 2013), and health (e.g., Fifer et al., 2018). The attraction to these types of models is that it allows researchers to derive the marginal utility that each product 


\section{THE WHO AND WHAT OF DEMAND FOR SMART METERS}

characteristic (attribute) contributes to each alternative under consideration. The models also allow researchers to derive an economic measure for each specific attribute, namely the willingness to pay (WTP). We use a MMLM framework, which belongs to the family of discrete choice models. This provides individual household WTP estimates for the different smart meter attributes that we examine.

\section{Proposed architecture for smart meter}

The proposed architecture consists of a modular approach (Fetttermann et al., 2017) which provides each individual household the possibility to monitor their usage of electricity, water and/or gas independently (Figure 1). The monitoring of each resource consumption is performed by a "slave" module, which communicates wirelessly with the "master" module. The system utilizes NRF24L01 wireless technology based on an Arduino processor and a standard font. Depending on each resource, the slave module presents a different sensor to consumption measurement. A flow transducer works as a sensor in order to observe water and gas consumption, while a current sensor is used to monitor energy consumption. All data provided can be stored in the cloud and accessed by a mobile application consistent with other recommended architectures (Lloret et al., 2016).

\section{[insert Figure 1]}

\section{The questionnaire}

The main section of the questionnaire consisted of a stated preference (SP) experiment, in which respondents were asked to choose among competing (hypothetical) smart meter configurations. The SP experiment provided the ground for modelling consumer preferences in terms of smart meter configuration. This technique is reliable and frequently used in the literature on this topic (e.g., Kaufmann et al., 2013; Albani et al., 2017; Mahmoodi et al., 2018).

In the DCE, alternatives were described by five attributes, namely the presence/absence of the smart meter for water, electricity and/or gas control, the availability of a mobile app, and the price for the specific configuration. The price levels for each specific smart meter configuration 


\section{THE WHO AND WHAT OF DEMAND FOR SMART METERS}

presented were defined as an increase/decrease of $10 \%$ from the existing market price. The costs for each of these configurations are presented in Appendix A. To create the SP experiment, a fractional factorial design (Hensher et al., 2015) was used, leading to four choice tasks $(s)$ with four alternatives $(a)$. However, the fourth alternative in choice tasks 3 and 4 were unrealistic (e.g., the offer of no meter for electricity, water or gas monitoring, but with a mobile app available) and therefore these were not presented to respondents. An example of a choice task undertaken by respondents is reported in Figure 2.

\section{[insert Figure 2]}

In addition to the SP experiment, other information was collected through the survey, regarding sociodemographic characteristics of the respondents and the home features of their residences (Table 1). We denote the classification of these variables into three groups according to their source, namely (i) smart meter attributes $(X)$, (ii) socio-demographics (Z), and (iii) home features $(W)$.

[insert Table 1]

The questionnaire was built using the Qualtrics ${ }^{\circledR}$ platform and made available online for respondents in Portuguese. An English version of the questionnaire is available from the authors upon request.

\section{Data collection}

The literature points out that socioeconomic variables (e.g., Martinsson et al., 2011), the locality (Ehrhardt-Martinez et al., 2010), as well as cultural and regional factors (Kull et al., 2014), can each affect surveys responses. In order to obtain a more representative sample of the population, this study focused on a specific region to improve the sample homogeneity and the possibility to replicate the study, as recommended by Forza (2002). The study was carried out in the metropolitan region of Florianopolis (latitude $27^{\circ} 35^{\prime} 49^{\prime \prime} \mathrm{S}$ and longitude $48^{\circ} 32^{\prime} 56^{\prime \prime} \mathrm{W}$ ), located in the south of Brazil. Florianopolis is the capital of the state of Santa Catarina and presents a humid subtropical climate with well-defined seasons. According to the last census conducted in 


\section{THE WHO AND WHAT OF DEMAND FOR SMART METERS}

2009, Florianopolis presents a HDI at 0.847 and its population was estimated to be 500,973 inhabitants. The number of inhabitants in its metropolitan region was estimated to be $1,012,233$ in 2010 (IBGE, 2020). The sampling was based on a non-probabilistic procedure. The questionnaire was published via the internet, similar to other surveys about smart meters (e.g., Vassileva and Campillo, 2016; Chen et al., 2017; Wunderlich et al., 2019). To ensure the sample was reflective of the population socio-demographics, respondents were invited to participate in the study using a variety of mediums. This included invitations online to using e-mail and social media (e.g., Facebook groups, LinkedIn). Other participants were invited by mail sent to community groups (e.g., retirement villages, alumni). A total of 300 responses were collected between August $20^{\text {th }}$ and September $30^{\text {th }}$ of 2018. Data cleaning led to the removal of incomplete responses and completed responses of those residing outside of the targeted region. This resulted in a final dataset consisting of 232 valid responses. Each respondent completed four choice tasks, resulting in a total of 928 observations for analysis.

\section{Econometric model}

Data collected via the SP experiment was modelled using a MMNL approach estimated in the willingness to pay space. The MMNL model assumes that preference parameters have a continuous distribution over the population, such that what is being estimated are not the preference parameters themselves, but rather structural parameters that represent the population level preference distribution. As with any typical DCM, a MMNL model is based on random utility theory, according to which consumers assign random utilities to each alternative and then select the one with the highest derived utility (Domencich and McFadden 1975).

With respect to parameterization of the model, we assume that the preference for attribute $k$ for person $n, \beta_{n k}$, follows a normal distribution. Rather than assume preferences are homogenous, we can further specify that,

$$
\beta_{n k}=\beta_{k_{m}}+\beta_{k_{s d}} * \eta_{n k}
$$

where $\beta_{k_{m}}$ and $\beta_{k_{s d}}$ represent the estimates of the two moments of the Normal distribution (i.e., mean and the standard deviation) and $\eta_{n k}$ is a random draw taken from a Normal distribution for 


\section{THE WHO AND WHAT OF DEMAND FOR SMART METERS}

respondent $n$. The resulting parameter is individual specific as it includes different draws for each respondent.

The utility function in a model estimated in WTP space is different from that reported for a model estimated in preference space as the coefficients of the former represent the marginal rate of substitution distributions and hence embody the ratio of two coefficients already. To specify the utility function of a MMNL in WTP space, we first separate the utility function into components that denote the costs of each alternative, $p$, and the remaining $k$ non-payment variables. The resulting utility function can then be re-written as:

$$
U_{n s j}=-\beta_{n p} x_{n p s j}+\sum_{k=1}^{K} \beta_{n k} x_{n k s j}+\varepsilon_{n s j}
$$

The negative $\beta_{n p}$ reflects the expectation that any increase in the cost variable should result in a decrease in the marginal utility of a given alternative. The error term of the model, $\varepsilon_{n s j}$, is assumed to be Extreme Value Type I distributed. It is possible to divide Equation (2) by the scale parameter, $\mu_{n}$, to assure that the error variances are invariant over respondents. That is,

$$
U_{n s j}=-\left(\beta_{n p} / \mu_{n}\right) x_{n p s j}+\sum_{k=1}^{K}\left(\beta_{n k} / \mu_{n}\right) x_{n k s j}+\varepsilon_{n s j}
$$

Defining $-\alpha_{n}=-\left(\beta_{n p} / \mu_{n}\right)$ and $\omega_{n k}=\left(\beta_{n k} / \mu_{n}\right)$, and substituting these into Equation (3) allows us to simplify the utility function as:

$$
U_{n s j}=-\alpha_{n} x_{n p s j}+\sum_{k=1}^{K} \omega_{n k} x_{n k s j}+\varepsilon_{n s j}
$$

The estimated parameters $\omega_{n k}$ represent the marginal rate of substitutions for the $k$-th attribute for respondent $n$. The parameters $\omega_{n k}$, as well as $\alpha_{n}$, represent random parameters (i.e., are characterized by structural parameters as per Equation 1) and therefore, simulation of draws is involved in the estimation of the model.

\section{RESULTS}

\section{Sample Characteristics}

Table 2 compares the sample and population of Florianopolis region profiles. The sample is younger than the actual population, which is common to other online surveys (e.g., Gerpott and Paukert, 2013, Chou and Yutami, 2014, Chou et al., 2015, Belton and Lunn, 2020). Specifically, 


\section{THE WHO AND WHAT OF DEMAND FOR SMART METERS}

it is composed of a larger number of 17 to 34 years old (about $20 \%$ more) and a lower number of $55+$ year old (about half) relative to the target population.

The census in Brazil collects limited information on home features, and when available, their accuracy is questionable owing to the high number of sub-dwellings. The last census indicated that there were 147,406 private households in Florianopolis (IBGE, 2020). However, this amount includes dwellings without city water or energy supply, and thereby these dwellings are deemed to be outside the scope of this research. Nonetheless, comparisons between the sample and population profiles based on the household size and rent-to-ownership ratio suggest a representative sampling strategy on these dimensions.

[Insert Table 2]

\section{Model Estimates}

Several model specifications were tested and compared with the final reported model chosen based on statistical goodness of fit indices, such as the log-likelihood function (LL), the Akaike Information Criteria (AIC) and the Bayesian Information Criteria (BIC), as well as behavioral correctness. The LL function is a logarithmic transformation of the likelihood function that measures the goodness of fit of a statistical model to a sample of data for given values of the unknown parameters (Fisher, 1922). The AIC and BIC estimate the amount of information lost by a model, with lower AIC and BIC values being indicative of relatively higher quality models. The AIC criterion takes into account the number of parameters included in the model and the LL value (Bozdogan, 1987). The formula of the BIC criterion also includes the number of observations used to estimate the model (Vrieze, 2012). The final model described in this paper presented the specification resulting in the highest LL value, and the lowest AIC and BIC values. The final model reported in this section is a MMNL with seven random parameters. The attributes of the SP experiment, namely the smart meters ability to monitor electricity (A), water (B) and gas (C), as well as the availability of monitoring the usage through the mobile app (D), are assumed to be Normal distributed, along with the alternative specific constant in the first utility function. In order to guarantee the negative sign of the estimate, the price parameter is assumed 


\section{THE WHO AND WHAT OF DEMAND FOR SMART METERS}

to be lognormal distributed. Finally, an error component (EC) included in the utility function describing the first alternative, which captures the common error associated with that alternative, is also assumed to be normal distributed. In addition to the main effects, the model also includes parameters capturing the interaction effects between each of the smart meter attributes with each of the dwelling characteristics. The dwelling variables describe each household's current type of power source $(\mathrm{H})$, ability to monitor and control individual water supply (I), residential property value $(\mathrm{J})$, contract type $(\mathrm{K})$, dwelling type (L), number of bedrooms $(\mathrm{M})$, size of household $(\mathrm{N})$, and type of gas system $(\mathrm{O})$.

Table 3 displays the estimates for the seven random parameters. These values represent the WTP for each specific attribute: a negative value suggests that respondents are willing to exchange that amount of money for receiving the equipment, whilst a positive value indicates that they are willing to accept (WTA) that device only if they receive compensation. The mean WTP for a smart meter device that allows monitoring of electricity and water is $\$ 793.65$ and $\$ 373.69$, respectively. Conversely, on average respondents want a compensation of $\$ 169.18$ to install a smart meter to monitor gas consumption. The results also indicate that respondents are WTP an average of $\$ 186.40$ to be able to use the mobile application to control resource expenditures.

The standard deviation parameter estimates allow a better understanding of the distribution of the WTP/WTA values. Following Chebyshev's theorem, at least $68 \%$ of the respondents will have preferences included within the range $(m \pm s t d . d e v), 95 \%$ within the range $(m \pm 2 s t d . d e v)$ and $99.7 \%$ within the range ( $m \pm 3$ std. $d e v$ ) (Black et al., 2018). Therefore, although on average respondents are WTA to install a smart meter to monitor gas consumption only if given a compensation of $\$ 169.18$, the large heterogeneity in the respondents' preferences suggests that part of the sample is WTP for installing a smart meter to monitor gas consumption (the range $(m \pm s t d . d e v)$ is $-\$ 587.49$ to $\$ 249.14)$.

[Insert Table 3] 


\section{THE WHO AND WHAT OF DEMAND FOR SMART METERS}

The values displayed in Table 4 further show how the average WTP values for each configuration vary for each particular household as function of their observable dwelling characteristics. The robust t-test value reported in brackets represents the test statistic associated with a null hypothesis that the difference between mean WTP for a smart meter attribute (in columns) is negligible as a function of a particular household characteristic (in rows). For example, the mean WTP for a smart meter that controls and monitors energy resources increases by $\$ 55.13$ for each additional bedroom in the dwelling (compared to the average value in the sample); as noted in Table 4, this is a significant variation in WTP at the .05 level. Similarly, the mean WTP for the smartphone app increases by $\$ 82.70$ for dwellings that currently have a water control system in their homes as compared to those who do not; this difference in mean WTP amounts is also significant.

\section{[Insert Table 4]}

The values reported in Table 4 can be employed to calculate the WTP for different dwelling profiles. To illustrate this, Table 5 reports three common profiles present in the population, which represent dwellings with differing characteristics based on the existing type of power source $(\mathrm{H})$, the existing ability to control individual water supply $(\mathrm{I})$, the residential property price $(\mathrm{J})$, existing contract type (K), type of dwelling (L), the number of bedrooms (M), the number of occupants in each household $(\mathrm{N})$ and the current gas system installed $(\mathrm{O})$. For example, the final table shows a comparison of dwellings with a relatively low, medium and high residential property values (J) whilst simultaneously varying other dwelling characteristics.

\section{[Insert Table 5]}

The WTP values for the different smart meter configurations can then be computed using the WTP values reported in Table 4 for each of the three dwelling profiles. As a matter of example, the WTP for the smart meter for monitoring the electricity consumption for Profile 1 presented in Table 5 is computed as: 


\section{THE WHO AND WHAT OF DEMAND FOR SMART METERS}

$$
\begin{gathered}
W T P_{\text {elec }}^{1}=-\$ 793.65+1 \times \$ 95.76+0 \times \$ 45.74+(2-2.8) \times(-\$ 29.20)+(2-2.66) \times \$ 55.15 \\
+1 \times \$ 39.48+1 \times(-\$ 90.55)+(79.963-145.215) \times(-\$ 0.14)
\end{gathered}
$$

Table 6 reports the average WTP values for the three general dwelling profiles for the inclusion of each of the three proposed smart meter configurations and value of the mobile app offering.

[Insert Table 6]

\section{DISCUSSION}

The purpose of the current research was to understand consumer preferences for various smart meter configurations to monitor electricity, water and/or gas in cases where this occurs with or without a mobile phone application. The model accounted for the proposition that household demand for such meters would differ based on household features, such as whether a dwelling type is a house or an apartment, the presence of individual water control, the type of power source, and the type of gas system.

The results indicate that eight of the thirteen sociodemographic / home characteristics considered in early modelling were shown to present as significant in determining variation in WTP for the four smart meter attributes (electricity, water, gas and app). The characteristics that were not significant and dropped from the final model were gender $(\mathrm{F})$, age $(\mathrm{H})$, electricity bill $(\mathrm{P})$, water bill (Q) and gas bill (R). Our results confirm that preferences for smart meters are entirely dependent on several home feature variables as highlighted in previous studies (e.g., Chen et al., 2017, Düstegör et al., 2018, Henn et al., 2019, Brown and Markusson, 2019, Belton Lunn, 2020). For example, our research is consistent with the significance of understanding variation in preferences for smart meters in relation to income (J) (e.g., Pepermans, 2014, Chen et al., 2017, Bugden and Stedman, 2019) and dwelling type (L) (Henn et al., 2019). The results also are consistent regarding the lack of significance of some tested variables, such as gender (F) (e.g., Chen et al., 2017; Düstegör et al., 2018), age (G) (e.g., Chen et al., 2017; Düstegör et al., 2018), contract type (K) (e.g., Düstegör et al., 2018), number of bedrooms (M) (e.g., Düstegör et al., 


\section{THE WHO AND WHAT OF DEMAND FOR SMART METERS}

2018; Henn et al., 2019) and household's monthly billing amounts (P, Q, R) (e.g., Düstegör et al., 2018). In contrast, our findings diverge from other studies regarding some variables such as age (e.g., Pepermans, 2014; Brown and Markusson, 2019; Bugden and Stedman, 2019; Belton and Lunn, 2020), gender (e.g., Bugden and Stedman, 2019; Belton and Lunn, 2020), income (Chen et al., 2017) and each household's monthly billing amounts (Chen et al., 2017). As such, our research corroborates previous studies on the literature about some variables but differs from others.

In addition, the model specification presented in this research reveals the importance of three new variables that have not been considered in the literature to date, namely variables describing a households' existing type source of power $(\mathrm{H})$, presence of individual water control (I) and type of type of gas supply (O). Similar to the type of power source, when households do not have water control devices already installed, smart meter configuration costs increase considerably. This is because flow sensors need to be installed as every water entry point. Also, all tenants living in dwellings without individual water control pay equal amounts for water usage in units regardless of their individual usage, which increases the number of unsatisfied customers (Peltomaa et al., 2020). With respect to gas supply (O), it is common in Brazil for cylinders to be used in residential gas supply (see Table 3), especially in houses. The standard gas cylinder weighs $13 \mathrm{~kg}$ when full, and their use provides only a rudimentary way to control gas consumption relative to smart meter technologies.

Our estimates of willingness to pay quantify consumer preferences for various smart meter features in terms of their monetary value (Hensher et al., 2015). Dantas et al. (2018) argue that the high cost estimated for smart meter configurations does not seem a barrier for a household's decision to acquire a smart meter. Our findings, do not support this proposition. However, we do note that the cost of devices and their installation is likely to reduce over time should large scale production be realized. Our research focuses on the billing costs from the viewpoint of consumers. However, our findings should also be considered more broadly with respect to the additional benefits that are offered for both consumers and suppliers with increased uptake of smart meters 


\section{THE WHO AND WHAT OF DEMAND FOR SMART METERS}

including the reduction of fraud (e.g., Yip et al., 2017), cost savings borne from automatic consumption reading (Sovacool et al., 2017), and improvements in forecasting (Abera and Khedar, 2020).

\section{CONCLUSION}

The results shed some light on the literature regarding the effect of many home features that presented a significant effect on customer decision regarding smart meter configuration. The significant effect of type of power supply, presence of individual water control and type of gas supply, which have not been previously tested so far, suggests how future models of smart meters implementation can be improved by the inclusion of these home features in forecasts. The improved comprehension of home feature variables on customer decisions regarding smart meter acquisition can also inform initiatives to overcome some barriers and maximise the success of smart meter rollout worldwide. Among the limitations of the study, the lack of a probabilistic sampling procedure harms the generalization of the results. Finally, the paper also brings valuable managerial information to develop better devices capable of fulfilling customer requirements. The understanding of customer preferences and its interaction between household feature variables can also support governmental or supplier initiatives for smart meter rollout, which is a crucial step to promote improvements in customer behaviour and consciousness regarding natural resource consumption.

\section{FUNDING}

This work was supported by Conselho Nacional de Desenvolvimento Científico e Tecnológico: [Grant Number 303936-2019-3]; Coordenação de Aperfeiçoamento de Pessoal de Nível Superior: [Grant Number Finance Code 001]. 


\section{THE WHO AND WHAT OF DEMAND FOR SMART METERS}

\section{REFERENCES}

Abera, F. Z. , \& Khedkar, V. (2020). Machine learning approach electric appliance consumption and peak demand forecasting of residential customers using smart meter data. Wireless Personal Communications , 111 (1), 65-82. $\underline{\text { Crossref }}$

Alahmad, M. A. , Wheeler, P. G. , Schwer, A. , Eiden, J. , \& Brumbaugh, A. (2012). A comparative study of three feedback devices for residential real-time energy monitoring. IEEE Transactions on Industrial Electronics , 59 (4), 2002-2013. Crossref

Albani, A. , Domigall, Y. , \& Winter, R. (2017). Implications of customer value perceptions for the design of electricity efficiency services in times of smart meters. Information Systems and e-Business Management , 15 (4), 825-844. $\underline{\text { Crossref }}$

Alkawsi, G. A. , Ali, N. A. , \& Alghushami, A. (2018). Toward understanding individuals' acceptance of internet of things-based services: Developing an instrument to measure the acceptance of smart meters. Journal of Theoretical and Applied Information Technology,96(13), 42654281. http://www.jatit.org/volumes/Vo196No13/26Vol96No13.pdf.

Anderson, W. , \& White, V. (2009). Exploring consumer preferences for home energy display functionality. Report to the Energy Saving Trust, 123, 1-49. Retrieved February de 24, 2020, from http://www.cse.org.uk/app/webroot/downloads/file/consumer_preferences for home energy d isplay.pdf

ANEEL . (2012). Resolução Normativa 502, de 7 de agosto, regulamenta sistemas de medição de energia elétrica consumidores do Grupo B. Retrieved February de 24, 2020, from http://www.aneel.gov.br/cedoc/ren2012502.pdf

Australian Energy Regulator (AER) . (2018). Smart meters. Retrieved February de 24, 2020, from https://www.aer.gov.au/consumers/my-energy-service/smart-meters\#about-smart-meters

Avancini, D. B. , Rodrigues, J. J. , Martins, S. G. , Rabêlo, R. A. , Al-Muhtadi, J. , \& Solic, P. (2019). Energy meters evolution in smart grids: A review. Journal of Cleaner Production, $217,702-715$. Crossref

Balta-Ozkan, N. , Boteler, B. , \& Amerighi, O. (2014). European smart home market development: Public views on technical and economic aspects across the United Kingdom, Germany and Italy. Energy Research \&amp; Social Science , 3, 65-77. Crossref

Belton, C. A. , \& Lunn, P. D. (2020). Smart choices? An experimental study of smart meters and time-ofuse tariffs in Ireland. Energy Policy, 140 , Article 111243. Crossref

Bertoldo, R. , Poumadère, M. , \& Rodrigues Jr., L. C. (2015). When meters start to talk: The public's encounter with smart meters in France. Energy Research \& Social Science , 9 , 146-156. Crossref

Black, K. , Asafu-Adjaye, J. , Burke, P., Perera, N. , Sherwood, C. , \& Wasimi, S. (2018). Business analytics and statistics. Wiley Publishing. ISBN 9780730363330.

Bonino, D. , Corno, F. , \& De Russis, L. (2012). Home energy consumption feedback: A user survey. Energy and Buildings , 47, 383-393. $\underline{\text { Crossref }}$

Bozdogan, H. (1987). Model selection and Akaike's information criterion (AIC): The general theory and its analytical extensions. Psychometrika, 52 (3), 345-370. $\underline{\text { Crossref }}$

Brown, C. J. , \& Markusson, N. (2019). The responses of older adults to smart energy monitors. Energy Policy, $130,218-226 . \underline{\text { Crossref }}$

Buchanan, K. , Russo, R. , \& Anderson, B. (2014). Feeding back about eco-feedback: How do consumers use and respond to energy monitors? Energy Policy, 73 , 138-146. Crossref

Buchanan, K. , Russo, R. , \& Anderson, B. (2015). The question of energy reduction: The problem (s) with feedback. Energy Policy, 77, 89-96. Crossref 


\section{THE WHO AND WHAT OF DEMAND FOR SMART METERS}

Bugden, D. , \& Stedman, R. (2019). A synthetic view of acceptance and engagement with smart meters in the United States. Energy Research \& Social Science, 47, 137-145. Crossref

Burke, P. F. (2013). Seeking simplicity in complexity: The relative value of ease of use (EOU)-based product differentiation. Journal of Product Innovation Management , 30 (6), 1227-1241. Crossref

Carvalho, P. (2015). Smart metering deployment in Brazil. Energy Procedia , 83 , 360-369. Crossref

Chen, C. F. , Xu, X. , \& Arpan, L. (2017). Between the technology acceptance model and sustainable energy technology acceptance model: Investigating smart meter acceptance in the United States. Energy Research \& Social Science , $25,93-104$. Crossref

Cherukutota, N. , \& Jadhav, S. (2016, April 6-8). Architectural framework of smart water meter reading system in IoT environment. Proceedings of International Conference IEEE communication and Signal Processing International Conference (ICCSP), (pp. 0791-0794), Melmaruvathur, India. Crossref

Chou, J. S. , Kim, C. , Ung, T. K. , Yutami, I. G. A. N. , Lin, G. T. , \& Son, H. (2015). Cross-country review of smart grid adoption in residential buildings. Renewable and Sustainable Energy Reviews , 48, 192213. $\underline{\text { Crossref }}$

Chou, J. S. , \& Yutami, I. G. A. N. (2014). Smart meter adoption and deployment strategy for residential buildings in Indonesia. Applied Energy, 128, 336-349. $\underline{\text { Crossref }}$

Dantas, G. D. A. , de Castro, N. J. , Dias, L., Antunes, C. H. , Vardiero, P. , Brandão, R. , Rosental, R. , \& Zamboni, L. (2018). Public policies for smart grids in Brazil. Renewable and Sustainable Energy Reviews , 92 , 501-512. Crossref

Darby, S. (2006). The effectiveness of feedback on energy consumption. A Review for DEFRA of the literature on metering, billing and direct displays, Environment Change Institute - University of $\begin{array}{lllll}\text { Oxford. } & \text { Retrieved } & \text { February 2020, }\end{array}$ from https://www.eci.ox.ac.uk/research/energy/downloads/smart-metering-report.pdf

Darby, S. (2008). Energy feedback in buildings: Improving the infrastructure for demand reduction. Building Research \& Information , 36 (5), 499-508. Crossref

Darby, S. (2010). Smart metering: What potential for householder engagement? Building Research \& Information, 38 (5), 442-457. Crossref

Davies, K. , Doolan, C. , Van den Honert, R. , \& Shi, R. (2014). Water-saving impacts of smart meter technology: An empirical 5 year, whole-of-community study in sydney. Australia. Water Resources Research , 50 (9), 7348-7358. $\underline{\text { Crossref }}$

Di Santo, K. G. , Kanashiro, E. , Di Santo, S. G. , \& Saidel, M. A. (2015). A review on smart grids and experiences in Brazil. Renewable and Sustainable Energy Reviews , 52, 1072-1082. Crossref

Domencich, T. A. , \& McFadden, D. (1975). Urban travel demand-a behavioral analysis (No. Monograph).

Düştegör, D. , Sultana, N. , Felemban, N. , \& Al Qahtani, D. (2018). A smarter electricity grid for the eastern province of Saudi Arabia: Perceptions and policy implications. Utilities Policy, 50 , 26-39. Crossref

Ehrhardt-Martinez, K. , Donnelly, K. A. , \& Laitner, S. (2010). Advanced metering initiatives and residential feedback programs: A meta-review for household electricity-saving opportunities (Report N. E105. American Council for an Energy-Efficient Economy Retrieved February de 24, 2020. https://www.aceee.org/sites/default/files/publications/researchreports/e105.pdf

Ellabban, O. , \& Abu-Rub, H. (2016). Smart grid customers' acceptance and engagement: An overview. Renewable and Sustainable Energy Reviews , 65 , 1285-1298. Crossref

European Union (EU) . (2009). Directive 2009/72/EC of the 13 July 2009. Concerning common rules for the internal market in electricity and repealing Directive 2003/54/EC. https://eurlex.europa.eu/LexUriServ/LexUriServ.do?uri=OJ:L:2009:211:0055:0093:EN:PDF Accessed on 24 February de 2020 


\section{THE WHO AND WHAT OF DEMAND FOR SMART METERS}

Fettermann, D. C., Cavalcante, C. G. S. , Ayala, N. F. , \& Avalone, M. C. (2020). Configuration of a smart meter for Brazilian customers. Energy Policy, 139, Article 111309. Crossref

Fettermann, D. C. , Echeveste, M. E. S. , \& Tortorella, G. L. (2017). The benchmarking of the use of toolkit for mass customization in the automobile industry. Benchmarking: An International Journal , 24 (6), 1767-1783. $\underline{\text { Crossref }}$

Fifer, S. , Rose, J. M. , Hamrosi, K. K. , \& Swain, D. (2018). Valuing injection frequency and other attributes of type 2 diabetes treatments in Australia: A discrete choice experiment. BMC Health Services Research , 18 (1), 675. Crossref PubMed.

Fischer, C. (2008). Feedback on household electricity consumption: A tool for saving energy? Energy Efficiency, 1 (1), 79-104. Crossref

Fisher, R. A. (1922). The goodness of fit of regression formulae, and the distribution of regression coefficients. Journal of the Royal Statistical Society , 85 (4), 597-612. Crossref

Forza, C. (2002). Survey research in operations management: A process-based perspective. International Journal of Operations \& Production Management , 22 (2), 152-194. Crossref

Gans, W. , Alberini, A. , \& Longo, A. (2013). Smart meter devices and the effect of feedback on residential electricity consumption: Evidence from a natural experiment in northern Ireland. Energy Economics , 36, 729-743. $\underline{\text { Crossref }}$

Gerpott, T. J. , \& Paukert, M. (2013). Determinants of willingness to pay for smart meters: An empirical analysis of household customers in Germany. Energy Policy, 61 , 483-495. Crossref

Giordano, V. , \& Fulli, G. (2012). A business case for smart grid technologies: A systemic perspective. Energy Policy, 40 , 252-259. Crossref

Greene, W. H. , \& Hensher, D. A. (2003). A latent class model for discrete choice analysis: Contrasts with mixed logit. Transportation Research Part B: Methodological , 37 (8), 681-698. Crossref

Henn, L. , Taube, O. , \& Kaiser, F. G. (2019). The role of environmental attitude in the efficacy of smartmeter-based feedback interventions. Journal of Environmental Psychology, 63, 74-81. Crossref

Hensher, D. A. , Rose, J. M. , \& Greene, W. H. (2015). Applied choice analysis (2nd ed.). Cambridge University Press. (p. 1188). Crossref.

Hutchinson, J. W. , Kamakura, W. A. , \& Lynch Jr., J. G. (2000). Unobserved heterogeneity as an alternative explanation for "reversal" effects in behavioral research. Journal of Consumer Research , 27 (3), 324 344. Crossref

Insitituto Brasileiro de Geografia e Estatística (IBGE) . (2020). Censo Demográfico. https://www.ibge.gov.br/

Jegen, M. , \& Philion, X. D. (2018). Smart grid development in quebec: A review and policy approach. Renewable and Sustainable Energy Reviews , 82 , 1922-1930. Crossref

Kaufmann, S. , Künzel, K. , \& Loock, M. (2013). Customer value of smart metering: Explorative evidence from a choice-based conjoint study in Switzerland. Energy Policy, 53 , 229-239. Crossref

Köhler, H. (2017). Individual metering and debiting (IMD) in Sweden: A qualitative long-term follow-up study of householders' water-use routines. Energy Policy, 108, 344-354. Crossref

Krishnamurti, T., Schwartz, D. , Davis, A. , Fischhoff, B. , de Bruin, W. B. , Lave, L. , \& Wang, J. (2012). Preparing for smart grid technologies: A behavioral decision research approach to understanding consumer expectations about smart meters. Energy Policy , 41, 790-797. Crossref

Kull, T. J. , Yan, T. , Liu, Z. , \& Wacker, J. G. (2014). The moderation of lean manufacturing effectiveness by dimensions of national culture: Testing practice-culture congruence hypotheses. International Journal of Production Economics , 153 , 1-12. Crossref 


\section{THE WHO AND WHAT OF DEMAND FOR SMART METERS}

Kumar, A. (2019). Beyond technical smartness: Rethinking the development and implementation of sociotechnical smart grids in India. Energy Research \& Social Science , 49, 158-168. Crossref

Lienert, F. , \& Carson, M. (2011). Smart meter roll-out for the domestic sector (GB), 2011. Retrieved February 24 ,

2020 , from https://assets.publishing.service.gov.uk/government/uploads/system/uploads/attachment data/fi le/48803/4906-smart-meter-rollout-domestic-ia-response.pdf

Liu, A., Giurco, D. , Mukheibir, P., Mohr, S. , Watkins, G. , \& White, S. (2017). Online water-use feedback: Household user interest. savings and implications. Urban Water Journal , 14 (9), 900-907. Crossref

Liu, A. , \& Mukheibir, P. (2018). Digital metering feedback and changes in water consumption-A review. Resources, Conservation and Recycling , 134 , 136-148. Crossref

Lloret, J. , Tomas, J. , Canovas, A. , \& Parra, L. (2016). An integrated IoT architecture for smart metering. IEEE Communications Magazine , 54 (12), 50-57. Crossref

Mahmoodi, J. , Prasanna, A. , Hille, S. , Patel, M. K. , \& Brosch, T. (2018). Combining "carrot and stick" to incentivize sustainability in households. Energy Policy, 123, 31-40. $\underline{\text { Crossref }}$

Martinsson, J., Lundqvist, L. J. , \& Sundström, A. (2011). Energy saving in Swedish households. The (relative) importance of environmental attitudes. Energy Policy, 39 (9), 5182-5191. Crossref

Marvin, S. , Chappells, H. , \& Guy, S. (1999). Pathways of smart metering development: Shaping environmental innovation. Computers, Environment and Urban Systems , 23 (2), 109-126. Crossref

McNair, B. J. , Bennett, J. , Hensher, D. A. , \& Rose, J. M. (2011). Households' willingness to pay for overhead-to-underground conversion of electricity distribution networks. Energy Policy, 39 (5), $\underline{\text { Crossref }}$

Mogles, N. , Walker, I. , Ramallo-González, A. P. , Lee, J. , Natarajan, S. , Padget, J. , Gabe-Thomas, E. , Lovett, T. , Ren, G. , Hyniewska, S. , \& O'neill, E. (2017). How smart do smart meters need to be? Building and Environment , 125, 439-450. Crossref

Montginoul, M. , \& Vestier, A. (2018). Smart metering: A water-saving solution? consider communication strategies and user perceptions first. evidence from a French case study. Environmental Modelling \& Software , 104, 188-198. Crossref

Owen, G. , \& Ward, J. (2006). Smart meters: Commercial, policy and regulatory drivers. Sustainability First. Retrieved February de 2020, from https://www.sustainabilityfirst.org.uk/images/publications/other/smart $\% 20$ meters $\% 20 \mathrm{pdf} \% 20 \mathrm{v}$ ersion.pdf

Peltomaa, J. , Mela, H. , \& Hildén, M. (2020). Housing managers as middle actors implementing sustainable housing policies in Finland. Building Research \& Information , 48 (1), 53-66. Crossref

Pepermans, G. (2014). Valuing smart meters. Energy Economics , 45 , 280-294. Crossref

Peters, D. , Axsen, J. , \& Mallett, A. (2018). The role of environmental framing in socio-political acceptance of smart grid: The case of British Columbia, Canada. Renewable and Sustainable Energy Reviews , 82 (part 2), 1939-1951. Crossref

Rausser, G. , Strielkowski, W. , \& Štreimikienė, D. (2018). Smart meters and household electricity consumption: A case study in Ireland. Energy \& Environment, 29 (1), 131-146. Crossref

Rhodes, J. D. , Upshaw, C. R. , Harris, C. B. , Meehan, C. M. , Walling, D. A. , Navrátil, P. A. , Beck, A. , Nagasawa, K. , Fares, R. , Cole, W. , Kumar, H., Duncan, R. , Holcomb, C. , Edgar, T. , Kwasinski, A. , \& Webber, M. (2014). Experimental and data collection methods for a large-scale smart grid deployment: Methods and first results. Energy , 65 , 462-471. Crossref 


\section{THE WHO AND WHAT OF DEMAND FOR SMART METERS}

Schultz, P. W. , Estrada, M. , Schmitt, J. , Sokoloski, R. , \& Silva-Send, N. (2015). Using in-home displays to provide smart meter feedback about household electricity consumption: A randomized control trial comparing kilowatts, cost, and social norms. Energy, 90, 351-358. Crossref

Schwartz, T. , Stevens, G. , Jakobi, T. , Denef, S. , Ramirez, L. , Wulf, V. , \& Randall, D. (2015). What people do with consumption feedback: A long-term living lab study of a home energy management system. Interacting with Computers , 27 (6), 551-576. Crossref

Siano, P. (2014). Demand response and smart grids-A survey. Renewable and Sustainable Energy Reviews , 30 , 461-478. $\underline{\text { Crossref }}$

Sovacool, B. K. , Kivimaa, P. , Hielscher, S. , \& Jenkins, K. (2017). Vulnerability and resistance in the United Kingdom's smart meter transition. Energy Policy, 109, 767-781. Crossref

Sønderlund, A. L. , Smith, J. R. , Hutton, C. J. , Kapelan, Z. , \& Savic, D. (2016). Effectiveness of smart meter-based consumption feedback in curbing household water use: Knowns and unknowns. Journal of Water Resources Planning and Management , 142 (12), 1-13. Crossref

Stewart, R. A., Nguyen, K. , Beal, C. , Zhang, H., Sahin, O. , Bertone, E., Vieira, A. S. , Castelletti, A., Cominola, A. , Giuliani, M. , Giurco, D. , Blumenstein, M. , Turner, A. , Liu, A. , Kenway, S. , Savic, D. A. , Makropoulos, C. , \& Kossieris, P. (2018). Integrated intelligent water-energy metering systems and informatics: Visioning a digital multi-utility service provider. Environmental Modelling \& Software , $105,94-117$. Crossref

Stewart, R. A. , Willis, R. M. , Panuwatwanich, K. , \& Sahin, O. (2013). Showering behavioural response to alarming visual display monitors: Longitudinal mixed method study. Behaviour \& Information Technology , 32 (7), 695-711. Crossref

Train, K. E. (2003). Discrete choice methods with simulation . Cambridge University Press. Crossref.

van de Kaa, G. , Rezaei, J. , Taebi, B. , van de Poel, I. , \& Kizhakenath, A. (2020). How to weigh values in value sensitive design: A best worst method approach for the case of smart metering. Science And Engineering Ethics , 26 (1), 475-494. Crossref PubMed.

van Houwelingen, J. H. , \& Van Raaij, W. F. (1989). The effect of goal-setting and daily electronic feedback on in-home energy use. Journal of Consumer Research, 16 (1), 98-105. Crossref

Vassileva, I. , \& Campillo, J. (2016). Consumers' perspective on full-scale adoption of smart meters: A case study in västerås, Sweden. Resources , 5 (1), 1-18. Crossref

Vassileva, I. , Dahlquist, E. , Wallin, F. , \& Campillo, J. (2013). Energy consumption feedback devices' impact evaluation on domestic energy use. Applied Energy, 106 , 314-320. Crossref

Vassileva, I. , Odlare, M. , Wallin, F. , \& Dahlquist, E. (2012). The impact of consumers' feedback preferences on domestic electricity consumption. Applied Energy , 93 , 575582. $\underline{\text { Crossref }}$

Vrieze, S. I. (2012). Model selection and psychological theory: A discussion of the differences between the akaike information criterion (AIC) and the Bayesian information criterion (BIC). Psychological Methods , 17 (2), 228. Crossref PubMed.

Wemyss, D. , Cellina, F. , Lobsiger-Kägi, E. , de Luca, V. , \& Castri, R. (2019). Does it last? long-term impacts of an app-based behavior change intervention on household electricity savings in Switzerland. Energy Research \& Social Science , 47 , 16-27. Crossref

Willis, K. G. , Scarpa, R. , \& Acutt, M. (2005). Assessing water company customer preferences and willingness to pay for service improvements: A stated choice analysis. Water Resources Research , 41 (2), W02019. Crossref

Wunderlich, P. , Veit, D. J. , \& Sarker, S. (2019). Adoption of sustainable technologies: A mixed-methods study of German households. MIS Quarterly , 43 (2), 673-691. Crossref 


\section{THE WHO AND WHAT OF DEMAND FOR SMART METERS}

Yang, B. , Liu, S. , Gaterell, M. , \& Wang, Y. (2019). Smart metering and systems for low-energy households: Challenges, issues and benefits. Advances in Building Energy Research , 13 (1), 80100. $\underline{\text { Crossref }}$

Yip, S. C. , Wong, K. , Hew, W. P. , Gan, M. T. , Phan, R. C. W. , \& Tan, S. W. (2017). Detection of energy theft and defective smart meters in smart grids using linear regression. International Journal of Electrical Power \& Energy Systems , 91 , 230-240. Crossref

Zehir, M. A. , Ortac, K. B. , Gul, H. , Batman, A., Aydin, Z. , Portela, J. C. , Soares, F. S. , Bagriyanik, M. , Kucuk, U. , \& Ozdemir, A. (2019). Development and field demonstration of a gamified residential demand management platform compatible with smart meters and building automation systems. Energies , 12 (5), 913-931. Crossref 


\section{THE WHO AND WHAT OF DEMAND FOR SMART METERS}

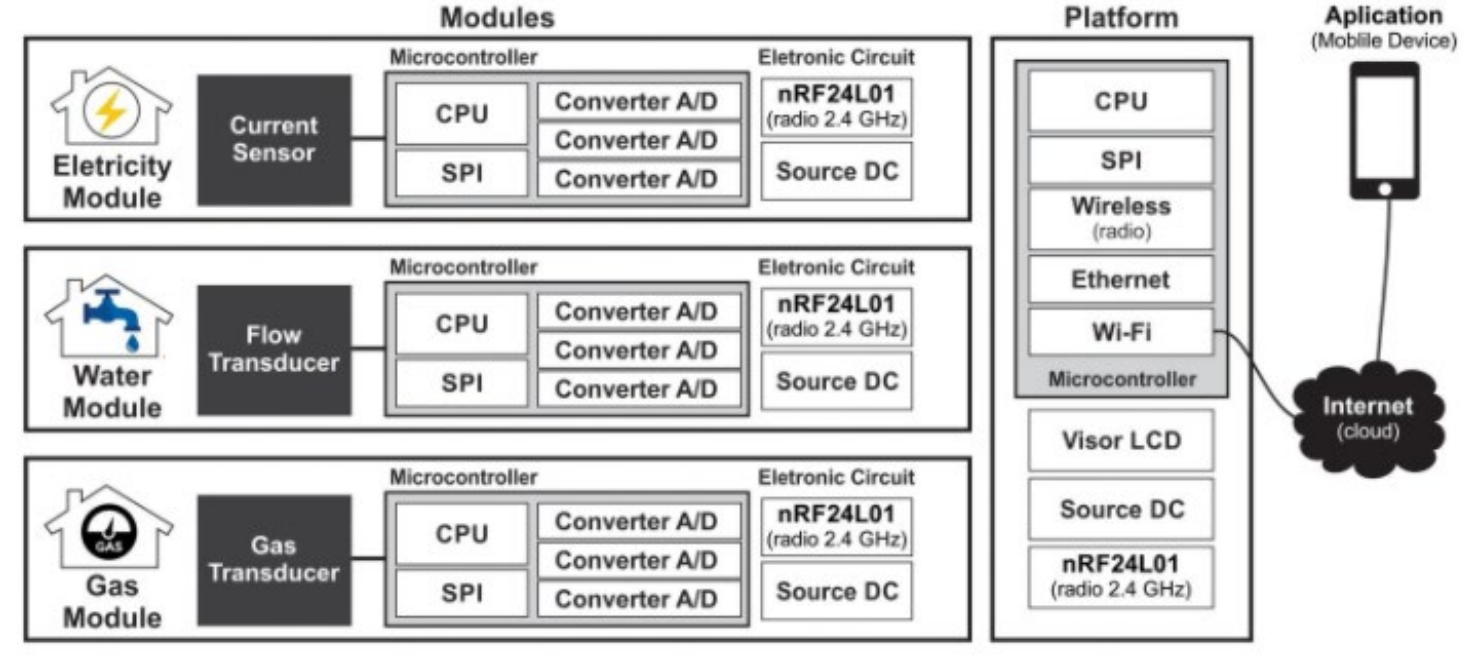

Figure 1: The smart meter architecture 

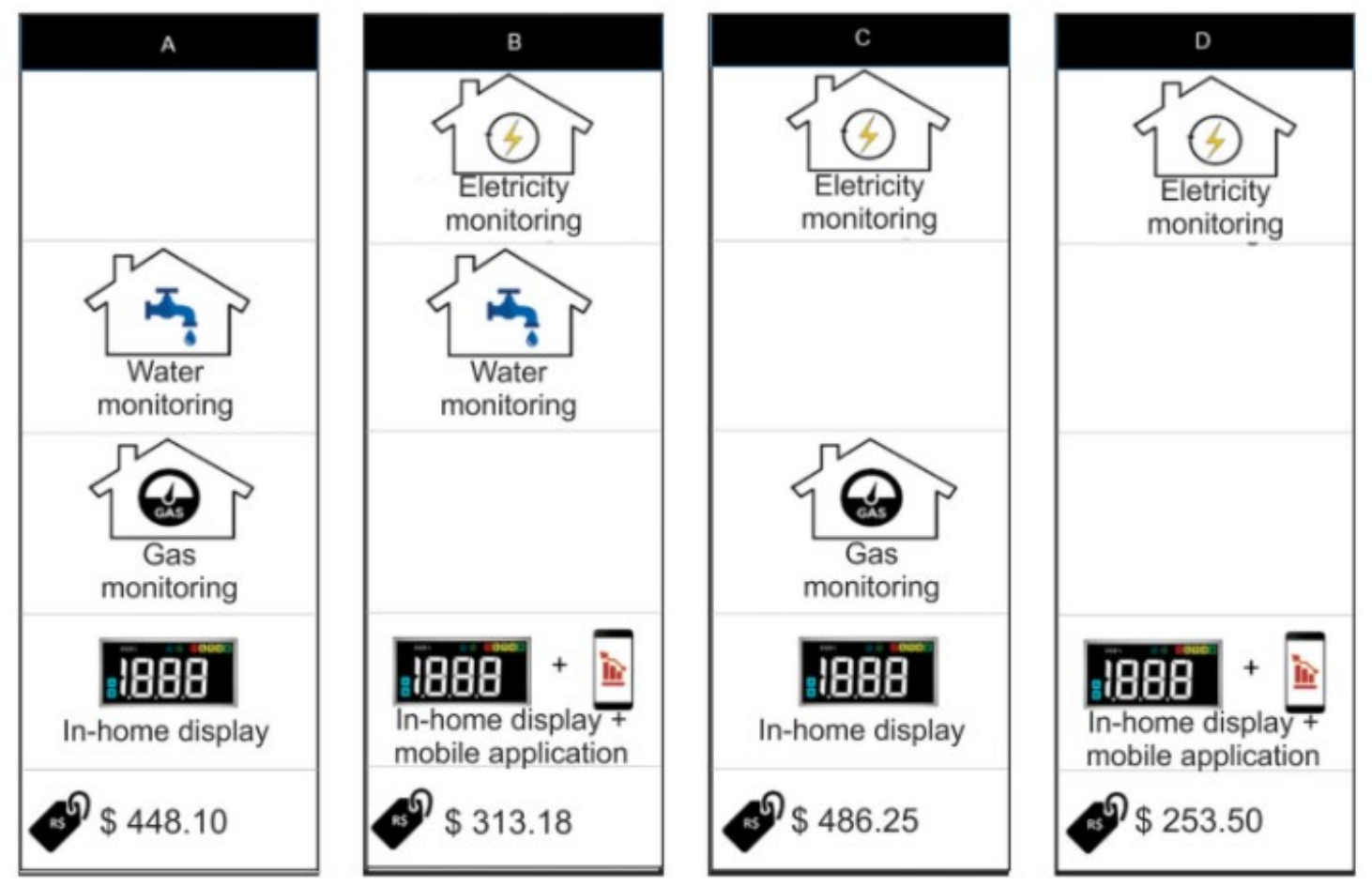

Figure 2: Example of choice task presented in questionnaire 


\section{THE WHO AND WHAT OF DEMAND FOR SMART METERS}

Table 1: Independent variables considered in the survey.

\begin{tabular}{|c|c|c|c|}
\hline ID & Subtitle & Variables & Description \\
\hline A & Smart meter & Electricity control & Yes $=1 / \mathrm{No}=0$ \\
\hline B & Smart meter & Water control & Yes $=1 / \mathrm{No}=0$ \\
\hline C & Smart meter & Gas control & Yes $=1 / \mathrm{No}=0$ \\
\hline D & Smart meter & Mobile application & Yes $=1 / \mathrm{No}=0$ \\
\hline \multirow[t]{2}{*}{ E } & \multirow[t]{2}{*}{ Smart meter } & \multirow[t]{2}{*}{ Price } & High $(>10 \%$ of configuration price $)=1$ \\
\hline & & & Low $(<10 \%$ of configuration price $)=0$ \\
\hline $\mathbf{F}$ & Sociodemographic & Gender & Female $=0 /$ Male $=1$ \\
\hline G & Sociodemographic & Age & Respondent's age in years \\
\hline H & Home & Type of power source & $\begin{array}{l}\text { Single-phase }=0 / \text { Two and Three } \\
\text { Phase }=1\end{array}$ \\
\hline I & Home & Individual water control & No $=0 /$ Yes $=1$ \\
\hline $\mathbf{J}$ & Home & $\begin{array}{l}\text { Residential property } \\
\text { price }\end{array}$ & Estimation of residence value \\
\hline K & Home & Contract type & Rented $=0 /$ Owned $=1$ \\
\hline $\mathbf{L}$ & Home & Dwelling type & House $=0 /$ Apartment $=1$ \\
\hline M & Home & Bedrooms & Number of bedrooms \\
\hline $\mathbf{N}$ & Home & Household size & Number of household's members \\
\hline $\mathbf{0}$ & Home & Gas system & Cylinder=0/Plated=1 \\
\hline $\mathbf{P}$ & Home & Electricity bill & Monthly electricity bill \\
\hline $\mathbf{Q}$ & Home & Water bill & Monthly water bill \\
\hline $\mathbf{R}$ & Home & Gas bill & Monthly gas bill \\
\hline
\end{tabular}


THE WHO AND WHAT OF DEMAND FOR SMART METERS

Table 2: Sample Characteristics:

\begin{tabular}{|c|c|c|c|}
\hline \multicolumn{4}{|c|}{ Population profile } \\
\hline Characteristics & Categories & Sample & Census (IBGE, 2010) \\
\hline $\begin{array}{l}\text { Number of private } \\
\text { homes }\end{array}$ & & 232 & 147,406 \\
\hline \multirow[t]{3}{*}{ Age } & Young (17-34 years old) & $65.94 \%$ & $43.08 \%$ \\
\hline & $\begin{array}{l}\text { Middle-aged ( } 35-54 \text { years } \\
\text { old) }\end{array}$ & $24.13 \%$ & $35.83 \%$ \\
\hline & Older (Over 55 years old) & $9.91 \%$ & $21.08 \%$ \\
\hline \multirow[t]{2}{*}{ Gender } & Male & $49.14 \%$ & $47.60 \%$ \\
\hline & Female & $50.86 \%$ & $52.40 \%$ \\
\hline \multicolumn{4}{|l|}{ Homes features } \\
\hline Characteristics & Categories & Sample & Census (IBGE, 2010) \\
\hline \multirow[t]{2}{*}{ Dwelling type } & Apartment & $58.19 \%$ & \\
\hline & House & $42.81 \%$ & \\
\hline \multirow[t]{2}{*}{ Property type } & Rented/borrowed & $36.63 \%$ & $30.10 \%$ \\
\hline & Owned & $63.37 \%$ & $69.90 \%$ \\
\hline \multirow[t]{5}{*}{ Household size } & 1 person & $15.09 \%$ & $17.53 \%$ \\
\hline & 2 persons & $32.76 \%$ & $28.32 \%$ \\
\hline & 3 persons & $25.00 \%$ & $25.17 \%$ \\
\hline & 4 persons & $17.24 \%$ & $17.89 \%$ \\
\hline & 5 persons or more & $9.91 \%$ & $11.09 \%$ \\
\hline \multirow[t]{2}{*}{ Type of power source } & Single-phase & $14.36 \%$ & $\mathrm{~N} / \mathrm{A}$ \\
\hline & Two-phase/Three-phase & $85.64 \%$ & N/A \\
\hline \multirow[t]{2}{*}{ Individual water control } & No & $46.98 \%$ & $\mathrm{~N} / \mathrm{A}$ \\
\hline & Yes & $53.02 \%$ & $\mathrm{~N} / \mathrm{A}$ \\
\hline \multirow[t]{3}{*}{ Type of GLP } & Cylinder & $53.88 \%$ & N/A \\
\hline & Plated & $46.12 \%$ & $\mathrm{~N} / \mathrm{A}$ \\
\hline & Sample Average & $\begin{array}{l}\text { Standard } \\
\text { Deviation }\end{array}$ & \\
\hline Property value & US\$ $145,214.64$ & US $\$ 9,837.62$ & \\
\hline Energy bill (month) & US\$ 43.75 & US\$ 30.91 & \\
\hline Water bill (month) & US\$ 24.46 & US\$ 21.36 & \\
\hline Gas Bill (month) & US\$ 16.55 & US\$ 16.90 & \\
\hline
\end{tabular}


THE WHO AND WHAT OF DEMAND FOR SMART METERS

Table 3: Attribute estimates

\begin{tabular}{lcccc}
\hline Variable & $\begin{array}{c}\text { Mean } \\
\text { parameters }\end{array}$ & $\begin{array}{c}\text { Robust std. } \\
\text { error }\end{array}$ & $\begin{array}{c}\text { Std. dev. } \\
\text { parameters }\end{array}$ & $\begin{array}{c}\text { Robust std. } \\
\text { error }\end{array}$ \\
\hline ASC & 56.90 & 1.44 & 129.11 & 1.74 \\
A-Electricity & -793.65 & 11.9 & 318.35 & 4.87 \\
B-Water & -373.69 & 3.77 & 360.00 & 3.67 \\
C-Gas & 169.18 & 8.72 & -418.31 & 4.68 \\
D-App & -186.40 & 9.68 & 35.42 & 0.54 \\
E-Price & -7.46 & 0.94 & 2.49 & 0.61 \\
EC & 24.70 & 1.19 & & \\
\hline
\end{tabular}


THE WHO AND WHAT OF DEMAND FOR SMART METERS

Table 4: WTP values for main and interaction effects

\begin{tabular}{|c|c|c|c|c|}
\hline & Energy & Water & Gas & App \\
\hline Mean & $\begin{array}{c}-\$ 793.65 \\
(-66.73)\end{array}$ & $\begin{array}{l}-\$ 373.69 \\
(-99.05)\end{array}$ & $\$ 169.18(19.41)$ & $\begin{array}{c}-\$ 186.40 \\
(-19.27)\end{array}$ \\
\hline $\begin{array}{l}\text { H-Type of power } \\
\text { source }\end{array}$ & $\begin{array}{l}-\$ 90.55 \\
(-16.37)\end{array}$ & $\begin{array}{l}-\$ 21.90 \\
(-11.46)\end{array}$ & $\begin{array}{l}-\$ 37.71 \\
(-21.63)\end{array}$ & $-\$ 48.58(-15.70)$ \\
\hline $\begin{array}{l}\text { I-Individual water } \\
\text { control }\end{array}$ & $-(-)$ & $\$ 57.06(27.85)$ & $\$ 60.51(20.96)$ & $\$ 82.70(30.96)$ \\
\hline $\begin{array}{l}\text { J-Residential property } \\
\text { price }\end{array}$ & $\begin{array}{l}-\$ 0.14 \\
(-8.77)\end{array}$ & $-\$ 0.04(-5.21)$ & $-\$ 0.06(-5.54)$ & $-\$ 0.35(-34.52)$ \\
\hline K-Contract type & $\begin{array}{l}\$ 45.74 \\
(12.89)\end{array}$ & $\$ 22.42(14.55)$ & $\$ 16.96(8.22)$ & $-\$ 57.70(-29.67)$ \\
\hline L-Dwelling type & $\begin{array}{l}\$ 95.76 \\
(30.38)\end{array}$ & $-(-)$ & $\begin{array}{l}-\$ 100.50 \\
(-21.51)\end{array}$ & $\$ 44.89(7.47)$ \\
\hline M-Bedrooms & $\begin{array}{l}\$ 55.15 \\
(25.53)\end{array}$ & $\$ 1.31(1.47)$ & $\$ 19.87(9.86)$ & $\$ 61.94$ (44.57) \\
\hline $\mathrm{N}-$ Household size & $\begin{array}{l}-\$ 29.20 \\
(-19.24)\end{array}$ & $\begin{array}{l}-\$ 33.67 \\
(-39.90)\end{array}$ & $-(-)$ & $-\$ 19.71(-14.73)$ \\
\hline O-Gas System & $\begin{array}{l}\$ 39.48 \\
(11.19)\end{array}$ & $\begin{array}{l}-\$ 84.72 \\
(-44.37)\end{array}$ & $\begin{array}{c}-\$ 216.35 \\
(-58.90)\end{array}$ & $-\$ 29.90(-8.67)$ \\
\hline
\end{tabular}

Note: Values in parentheses represent robust t-test statistics indicating the significant differences in mean WTP amounts. The symbols - (-) identify the parameters that were not inserted in the final model as they resulted to be not significant in modelling phase. The WTP for Residential property price is considered for increments of $\$ 1,000$ compared to the average value. The WTP for the continuous variables (household size, bedrooms, residential property price) are compared to the WTP amount for the average of each variable. The WTP for the categorical variables (dwelling type, contract type, gas system, type of power source, individual water control) are compared to the base categories indicated by a 0 in Table 1 . 


\section{THE WHO AND WHAT OF DEMAND FOR SMART METERS}

Table 5. Dwelling profiles and WTP values.

\begin{tabular}{lcccccccc}
\hline Dwelling profiles & H & I & J & K & L & M N & O \\
\hline Profile 1 & Bi-Three Phases & No & $\$ 79,963.00$ & Rented & Apartment & 2 & 2 & Plated \\
Profile 2 & Bi-Three Phases & Yes & $\$ 271,700.00$ & Own & House & 3 & 5 & Cylinder \\
Profile 3 & Bi-Three Phases & Yes & $\$ 134,862.00$ & Rented & Apartment & 3 & 3 & Plated \\
\hline
\end{tabular}

Note: $\$$ is US\$. 1 US\$= R 4.39 (Brazilian currency). 


\section{THE WHO AND WHAT OF DEMAND FOR SMART METERS}

Table 6. WTP values for different dwelling profiles.

\begin{tabular}{lcclc}
\hline \multirow{2}{*}{ Dwelling profiles } & \multicolumn{4}{c}{ WTP } \\
& A-Electricity & B-Water & \multicolumn{1}{c}{ C-Gas } & D-App \\
\hline Profile 1 & $-\$ 753.02$ & $-\$ 451.52$ & $-\$ 194.75$ & $-\$ 222.27$ \\
Profile 2 & $-\$ 902.18$ & $-\$ 395.28$ & $\$ 208.22$ & $-\$ 277.40$ \\
Profile 3 & $-\$ 689.12$ & $-\$ 406.76$ & $-\$ 100.62$ & $-\$ 174.50$ \\
\hline Note: $\$$ is US\$. 1 US\$ $=\mathrm{R} \$ 4.39$ (Brazilian currency)
\end{tabular}

